\author{
BULETINUL INSTITUTULUI POLITEHNIC DIN IAŞI \\ Publicat de \\ Universitatea Tehnică „Gheorghe Asachi” din Iaşi \\ Volumul 67(71), Numărul 1,2021 \\ Secţia \\ CONSTRUCTTII. ARHITECTURĂ \\ DOI: $10.2478 /$ bipca-2021-0006 \\ sciendo
}

\title{
SHEAR LAG AND LOCAL BUCKLING INTERACTION IN ORTHOTROPIC DECK OF STEEL BRIDGES
}

BY

\section{CĂTĂLIN MOGA, ${ }^{1 *}$ CRINA FENESAN and MIRCEA SUCIU}

\author{
Technical University of Cluj-Napoca
}

Faculty of Civil Engineering

Received: February 21, 2021

Accepted for publication: March 04, 2021

Abstract. The term of shear lag is related to the discrepancies between the approximate theory of the bending of beams and their real behaviour, and it refers to the increases of the bending stresses near the flange-to-web junctions, and the corresponding decreases in the flange stresses away from these junctions.

In the case of wide flanges of plated structures, shear lag caused by shear strains, which are neglected in the conventional theory, may be taken into account by a reduced flange width concentrated along the webs of the steel girders.

The effects of the shear lag, plate buckling and interaction of both effects should be taken into account at the ultimate, serviceability or fatigue limit states in the design of structures with wide flanges.

In EN 1993-1-5, the concept of taking shear lag into account is based on the effectives width of the flange which is defined in order to have the same total normal force in the gross flange subjected to the real transverse stress distribution as the effective flange subjected to a uniform stress.

Some aspects concerning the shear lag phenomenon and a design example of effectives width calculation and the shear lag effects for a steel pedestrian bridge deck are presented in this paper.

Keywords: Shear lag, steel bridges, orthotropic deck, Eurocodes EN1993-15 and EN 1993-2.

$1 *$ Corresponding author; e-mail: Crina.Fenesan@cfdp.utcluj.ro

(C) 2021 Cătălin Moga, Crina Fenesan and Mircea Suciu

This is an open access article licensed under the Creative Commons Attribution-NonCommercial-

NoDerivatives 4.0 International License (CC BY-NC-ND 4.0). 


\section{Introduction}

In the conventional theory of bending, the shear strains are neglected so it can be assumed that the plane sections remain plane after loading. From this assumption and based on the Bernoulli's linear elastic hypothesis, the simple linear distributions of the bending strains and stresses results.

The term shear lag is related to some of the discrepancies between this approximate theory of the bending of beams and their real behaviour, and in particular, it refers to the increases of the bending stresses near the flange-to-web junctions, and the corresponding decreases in the flange stresses away from these junctions (Trahair et al., 2008).

In the case of wide flanges of plated structures, the shear lag may be taken into account by a reduced flange width concentrated along the webs, that has to be taken into account for the verification of stresses, especially for short spans, since it causes the longitudinal stress at a flange/web intersection to exceed the average stress in the flange.

Shear lag effects may be significant in stiffened box girders and generally in structures with large width of the flange, Fig. 1.
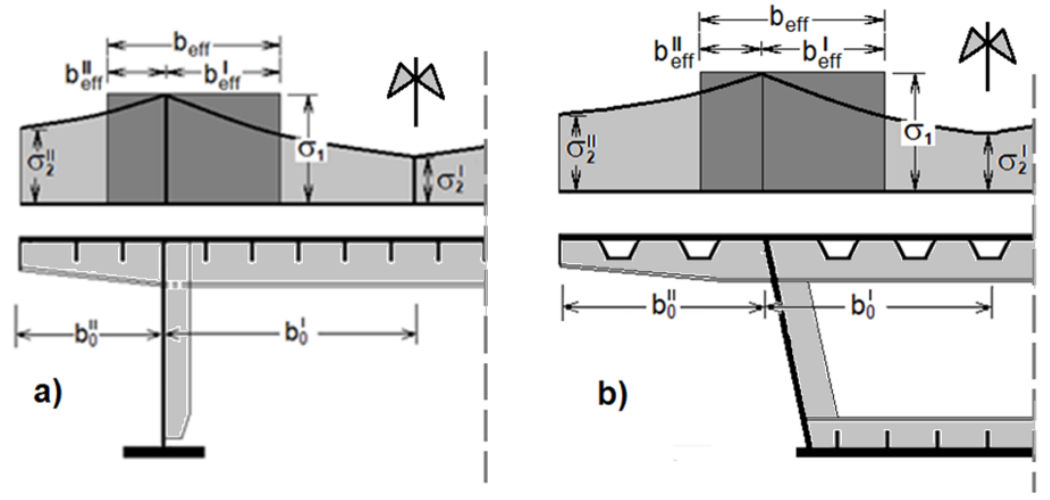

Fig. 1 - Effective width due to shear lag: a) open section girder with a wide top flange; b) box girder with an orthotropic deck

An approximate method of dealing with shear lag is to use an effective width concept, in which the actual width $b$ of a flange is replaced by a reduced width $b_{\text {eff }}$.

This approach is similar to that used to allow for the redistribution of stress which takes place in a thin compression flange after local buckling but, the two effects of shear lag and local buckling are quite distinct, and should not be confused (Trahair et al., 2008). 
In relation to the effective width method, SR EN 1993-1-5.\$3.3 introduces three different designations for three types of effective width SR EN 1993-1-5: 2006. Eurocod 3 (EC3-1-5); Beg et al, 2010; Johansson et al., 2007:

- Effective ${ }^{\mathrm{s}}$ width - shear lag effects;

- Effective $^{\mathrm{p}}$ width - local buckling of plates;

- Effective width - interaction of shear lag and local buckling.

When designing plated structures, the effects of shear lag, plate buckling and interaction of both effects should be taken into account at the ultimate, serviceability or fatigue limit states.

Shear lag can occur in the tension flange as well as in the compression flange, when interaction should be considered between shear lag and pale buckling effects.

For simplicity the effective ${ }^{\mathrm{s}}$ width can be taken as constant over the length of each span:

$$
b_{\text {eff }}=\min \left(b_{0} ; L_{i} / 8\right)
$$

\section{Effective ${ }^{\mathrm{s}}$ Width for Elastic Shear Lag Analysis}

In EN 1993-1-5, the concept of taking the shear lag into account is based on the effective ${ }^{\mathrm{s}}$ width of the flange which is defined in order to have the same total normal force in the gross flange subjected to the real transverse stress distribution as the effective flange subjected to a uniform stress equal to the maximum stress of the real transverse distribution:

where:

$$
\int_{0}^{b} \sigma_{x}(y) \cdot t_{f} \cdot d y=b_{\text {eff }} \cdot t_{f} \cdot \sigma_{x . \max }
$$

$-b_{\text {eff }}=\beta \cdot b_{0}$;

- $\beta$ is an efficiency factor given in Table 1.

Table 1

Coefficient $\beta$ evaluation

\begin{tabular}{|c|c|c|}
\hline $\begin{array}{c}\text { Location for } \\
\text { verification }\end{array}$ & $\boldsymbol{\beta}$ - value & $\mathbf{k}$ \\
\hline & $\beta=1.0$ & $\leq 0.02$ \\
\hline
\end{tabular}




\begin{tabular}{|c|c|c|}
\hline $\begin{array}{c}\text { Location for } \\
\text { verification }\end{array}$ & $\boldsymbol{\beta}$ - value & $\mathbf{k}$ \\
\hline $\begin{array}{c}\text { Regions of } \\
\text { positive } \\
\text { (sagging) } \\
\text { bending }\end{array}$ & $\beta=\beta_{1}=\frac{1}{1+6.4 \cdot k^{2}}$ & $0.02-0.70$ \\
\cline { 2 - 3 } & $\beta=\beta_{2}=\frac{1}{5.9 \cdot k}$ & $>0.70$ \\
\hline $\begin{array}{c}\text { Regions of } \\
\text { negative } \\
\text { (hogging) } \\
\text { bending }\end{array}$ & $\beta=\beta_{2}=\frac{1}{8.6 \cdot k}$ & $>0.02-0.70$ \\
\cline { 2 - 4 } & $\beta_{0}=\left(0.55+\frac{1}{2500 \cdot k}\right)+1.6 \cdot k^{2}$ & all $k$ values \\
\hline $\begin{array}{c}\text { Linear } \\
\text { bending on } \\
\text { end supports }\end{array}$ & $\beta=\beta_{2}$ at support and at the end $\beta_{0}<\beta_{1}$ & all $k$ values \\
\hline Cantilever & $\beta .0 .70$ \\
\hline
\end{tabular}

where:

$$
\text { - factor related to the stiffening ratio } \alpha_{0}
$$

$$
\begin{aligned}
& k=\frac{\alpha_{0} \cdot b_{0}}{L_{e}} \\
& \alpha_{0}=\sqrt{1+\frac{A_{s l}}{b_{0} \cdot t}} \quad \text { - orthotropic plate factor }
\end{aligned}
$$

In which: $\sum A_{s l}$ is the area of all longitudinal stiffeners on $b_{0}$ width and $L_{e}$ is the effective length in accordance with SR EN 1993-1-5: 2006. Eurocod 3 (EC3-1-5).

Provided adjacent spans do not differ more than $50 \%$ and any cantilever span is not larger than half of the adjacent span and the effective lengths $L_{e}$ may be determined from Fig. 2. For all the other cases $L_{e}$ should be taken as the distance between adjacent points of the zero bending moment (SR EN 1993-1-5: 2006. Eurocod 3 (EC3-1-5)). 

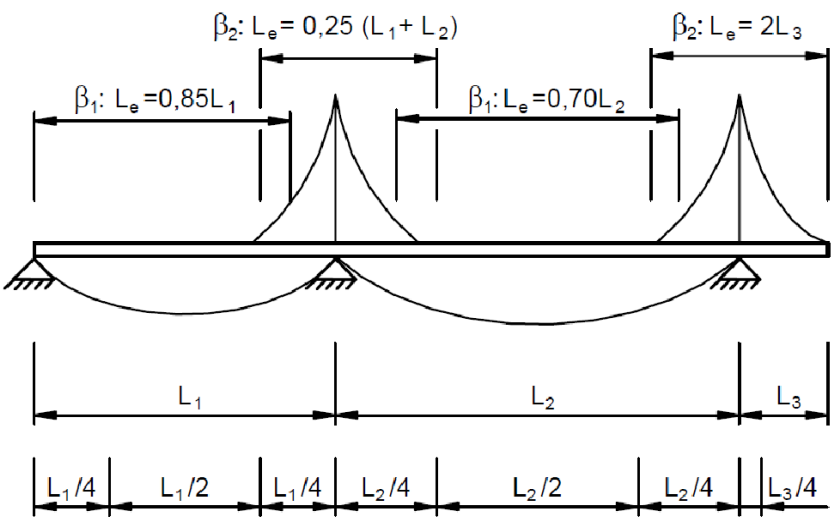

$\beta_{0}$

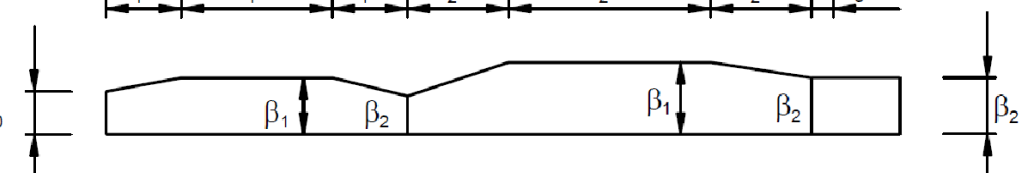

Fig. 2 - Definition of the effective length $L_{e}$

The transverse bending stresses distribution due to shear lag, Fig. 3, is given by the relations (SR EN 1993-1-5: 2006. Eurocod 3 (EC3-1-5)):

If:

$$
\beta>0.2:\left\{\begin{array}{l}
\sigma_{2}=1.25(\beta-0.20) \sigma_{1} \\
\sigma(y)=\sigma_{2}+\left(\sigma_{1}-\sigma_{2}\right)\left(1-\frac{y}{b_{0}}\right)^{4}
\end{array}\right.
$$

If:

$$
\beta \leq 0.2:\left\{\begin{array}{l}
\sigma_{2}=0 \\
\sigma(y)=\sigma_{1}\left(1-\frac{y}{b_{1}}\right)^{4}
\end{array}\right.
$$



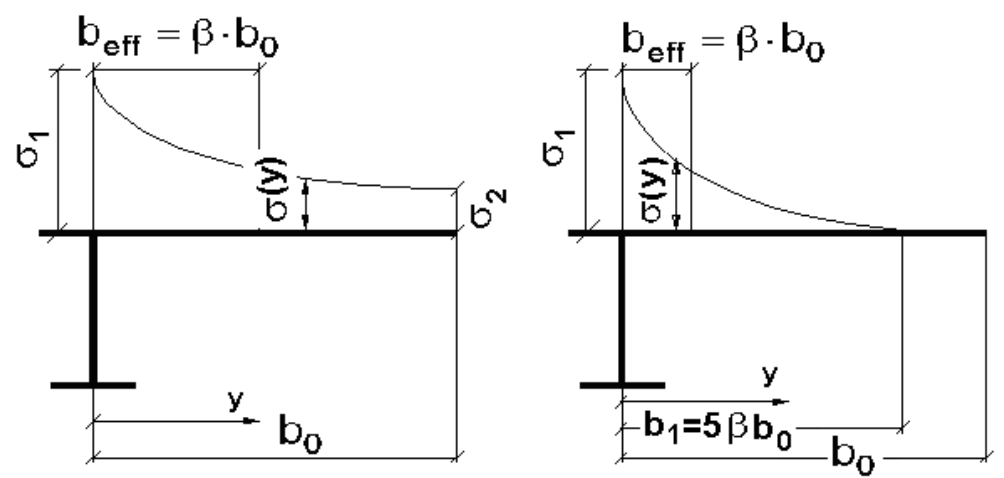

Fig. 3 - Distribution of stresses due to shear lag

According to EN 1993-1-5, the shear lag in the flanges can be neglected if $b_{0}<L_{e} / 50$.

It should be noticed that, the more stiffened the flange is, the smaller its effective $e^{\mathrm{s}}$ width is, but this influence is not so important in hogging bending region (Beg et al, 2010).

\section{Interaction Between the Shear Lag and the Llate Buckling at ULS}

In case of a flange in compression at ULS (ultimate limit state) verification, the plate buckling effects which results in an effective ${ }^{\mathrm{p}}$ area of the flange may occur in addition to the shear lag effects.

At the ultimate limit state shear lag effects may be determined as follows (SR EN 1993-1-5: 2006. Eurocod 3 (EC3-1-5)):

a) elastic shear lag effects as determined for serviceability and fatigue limit states; b) combined effects of shear lag and of plate buckling;

c) elastic-plastic shear lag effects allowing for limited plastic strains.

EN 1993-1-5 proposes two models of steps for interaction between shear lag and plate buckling (SR EN 1993-1-5: 2006. Eurocod 3 (EC3-1-5); Beg et al, 2010; Johansson et al., 2007):

Model 1 (method b):

- Calculate the effective $\mathrm{p}^{\mathrm{p}}$ area to plate buckling; 
- Define an effective $e^{\mathrm{p}}$ stiffening ratio $\alpha_{0}^{*}$ to be used instead of the stiffened ratio $\alpha_{0}$ and calculating the reduction factor $\beta_{\text {ult }}$ (using Table 1) instead of $\beta$, where:

$$
\alpha_{0}^{*}=\sqrt{\frac{A_{c . e f f}}{b_{0} \cdot t}}
$$

- Calculate the effective area $\mathrm{A}_{\text {eff }}$ for taking shear lag and plate buckling effects into account as follows:

$$
A_{\text {eff }}=\beta_{\text {ult }} \cdot A_{\text {c.eff }}
$$

Model 2 (method c-recommended in EN 1993-1-5):

- An elastoplastic reduction factor $\beta^{k} \geq \beta$ is directly applied to the effective $\mathrm{e}^{\mathrm{p}}$ area of the compression flange, where $\mathrm{k}$ is based on $\alpha_{0}$ :

$$
A_{\text {eff }}=\beta^{k} \cdot A_{c . e f f} \geq A_{c . e f f} \cdot \beta
$$

It is recommended to apply the reduction factor of the area to the thickness of the plate, and not to the width (Beg et al, 2010; Johansson et al., 2007).

\section{Design Examples}

In paper (Moga C., Fenesan C., Suciu M.: Effective width of steel flange girders related to shear lag phenomenon. BUT „Gh. Asachi”. Vol. 66. Nr. $1 / 2020$ ) two structures from the shear lag point of view were analyzed, one of a steel superstructure road bridge and another one of a footbridge, respective the effective ${ }^{\mathrm{s}}$ width of a tension flange and the shear lag at the ultimate limit state effects for a composite steel-concrete girder.

A working example for a box girder of a heavy crane runway to illustrate the determination of the shear lag effect is also presented in paper (Moga, C., Drăgan, D., Nerişanu, R.: Effects of Shear Lag in Steel Box Girders of a Crane Runway. Ovidius University Annals Series: Civil Engineering. 2020).

Other design examples and information are presented in the handbook (Moga, P.: Euronorme. Calculul elementelor metalice, 2018 and Moga, P., et al.: Pasarele pietonale, 2020).

In this example the shear lag phenomenon in a steel deck of a pedestrian bridge girder is analyzed. The bridge superstructure is a steel box girder, simple supported with a span equal of $20.00 \mathrm{~m}$. The steel grade used in structure is S355. presented.

In Fig. 4 the steel deck dimensions and the component elements are 


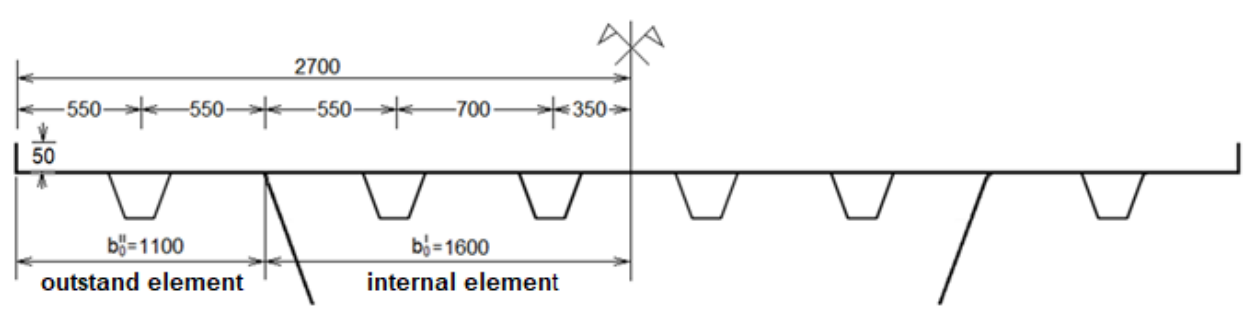

Fig. 4 - Steel deck dimensions

In this case $b_{0}>L_{e} / 50=400 \mathrm{~mm}$, and in consequence the shear lag has to be taken into consideration.

\section{Calculation of the gross area of subpanels}

The dimensions of the steel deck panels are presented in Fig. 5.
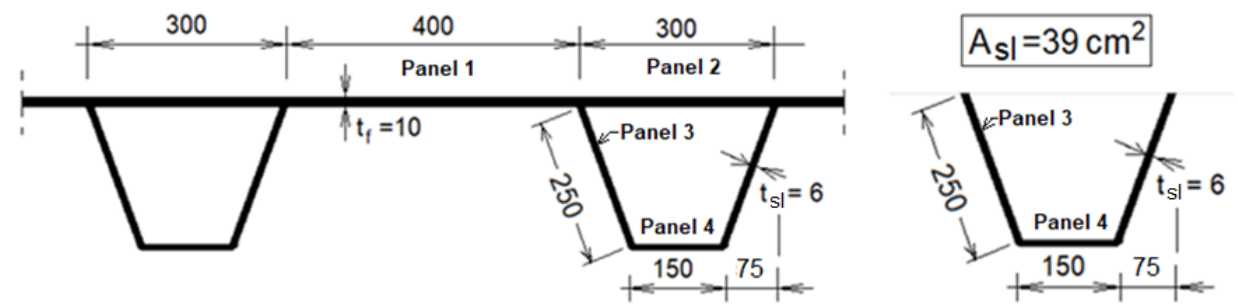

Fig. 5 - Dimensions of steel deck panels

The gross cross section area of the steel deck is presented in Fig. 6.

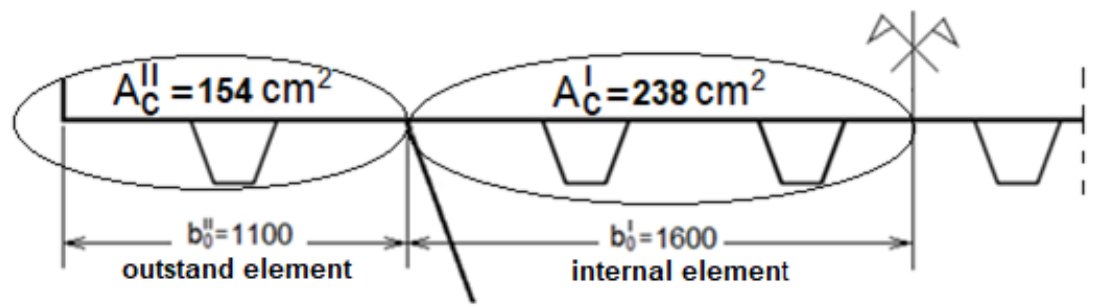

Fig. 6 - Gross cross - section area of the steel deck 


\section{Calculation of the effective $\mathrm{e}^{\mathrm{p}}$ area of subpanels}

The sub-panel widths are taken conservatively equal with the interaxle distances.

\section{Panel 1}

$$
\begin{aligned}
& \bar{\lambda}_{p 1}=\frac{b_{1} / t}{28.4 \cdot \varepsilon \cdot \sqrt{k_{\sigma}}}=\frac{400 / 10}{28.4 \cdot 0.81 \cdot \sqrt{4}}=0.869>0.673 \\
& \rho_{1}=\frac{\bar{\lambda}_{p 1}-0.055(3+\Psi)}{\bar{\lambda}_{p 1}^{2}}=\frac{0.869-0.055(3+1)}{0.869^{2}}=0.86 \\
& \Rightarrow b_{1 . e f f}=\rho_{1} \cdot b_{1}=0.86 \cdot 400=344 \mathrm{~mm}
\end{aligned}
$$

\section{Panel 2}

$$
\bar{\lambda}_{p 2}=\frac{b_{2} / t}{28.4 \cdot \varepsilon \cdot \sqrt{k_{\sigma}}}=\frac{300 / 10}{28.4 \cdot 0.81 \cdot \sqrt{4}}=0.326<0.673 \Rightarrow \rho_{2}=1
$$

\section{Panel 3}

$$
\begin{gathered}
\bar{\lambda}_{p 3}=\frac{b_{3} / t_{s \ell}}{28.4 \cdot \varepsilon \cdot \sqrt{k_{\sigma}}}=\frac{250 / 6}{28.4 \cdot 0.81 \cdot \sqrt{4}}=0.906>0.673 \\
\rho_{3}=\frac{\bar{\lambda}_{p .3}-0.055(3+\Psi)}{\bar{\lambda}_{p 3}^{2}}=\frac{0.906-0.055(3+1)}{0.906^{2}}=0.836 \\
\Rightarrow b_{3 . \text { eff }}=\rho_{3} \cdot b_{3}=0.836 \cdot 250=210 \mathrm{~mm}
\end{gathered}
$$

\section{Panel 4}

$$
\bar{\lambda}_{p 4}=\frac{b_{4} / t_{s \ell}}{28.4 \cdot \varepsilon \cdot \sqrt{k_{\sigma}}}=\frac{150 / 6}{28.4 \cdot 0.81 \cdot \sqrt{4}}=0.543<0.673 \Rightarrow \rho_{4}=1
$$

The effective ${ }^{\mathrm{p}}$ panel areas are presented in Fig. 7.
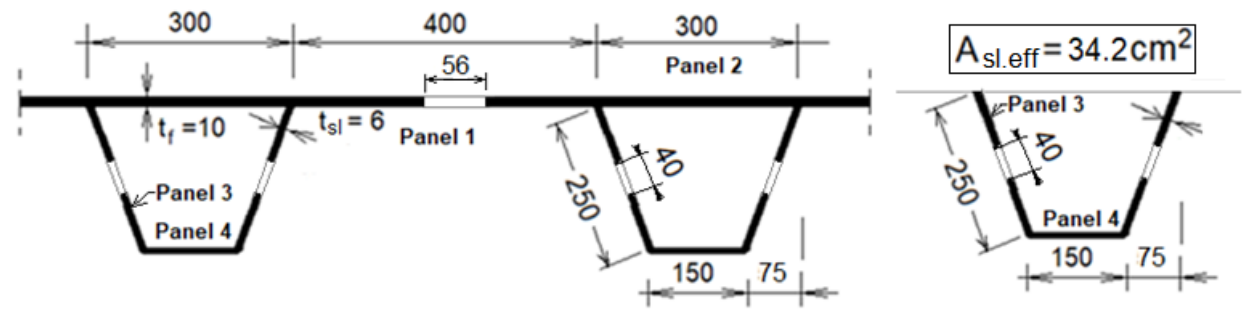

Fig. 7 - Effective ${ }^{\mathrm{p}}$ panel areas

In Fig. 8 the effective ${ }^{p}$ panel areas of the internal and the outstand elements are presented. 


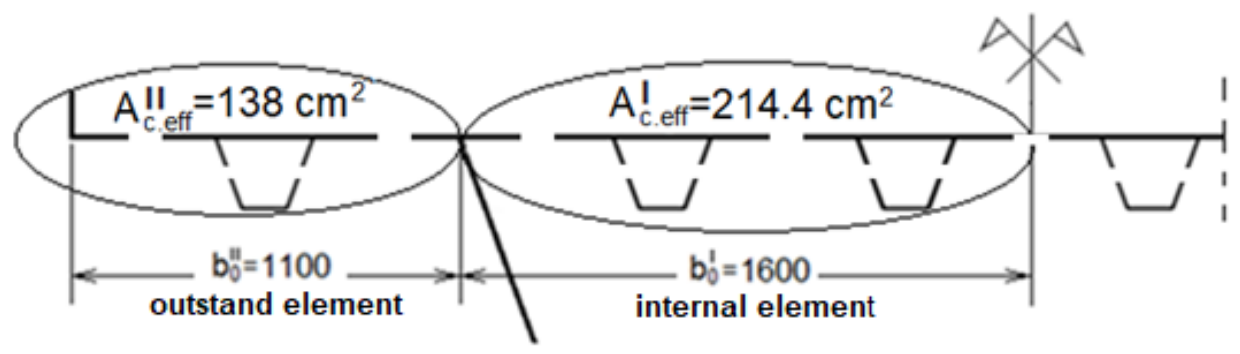

Fig. 8 - Effective ${ }^{\mathrm{p}}$ panel areas of internal and outstand elements

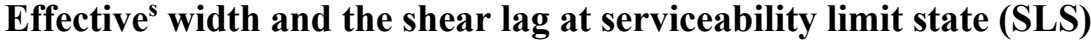

The coefficients $\alpha_{0}$ for the internal element (I) and for the outstand element (II) of the orthotropic plate, Fig. 5 and Fig. 6, are:

$$
\alpha_{0}^{I}=\sqrt{1+\frac{2 \cdot 39}{160 \cdot 1.0}}=1.22 ; \quad \alpha_{0}^{I I}=\sqrt{1+\frac{1 \cdot 39}{110 \cdot 1.0}}=1.16
$$

For an effective length $\mathrm{L}_{\mathrm{e}}=20.0 \mathrm{~m}$, it is obtained as follows:

- Internal element:

$$
\begin{gathered}
k_{I}=\frac{\alpha_{0}^{I} \cdot b_{0}^{I}}{L_{e}}=\frac{1.22 \cdot 160}{2000}=0.098 \\
\beta^{I}=\beta_{1}^{I}=\frac{1}{1+6.4 \cdot k^{2}}=\frac{1}{1+6.4 \cdot 0.098^{2}}=0.94 \\
b_{\text {eff }}^{I}=\beta_{1}^{I} \cdot b_{0}^{I}=0.94 \cdot 1600=1504 \mathrm{~mm}
\end{gathered}
$$

- Outstand element:

$$
\begin{gathered}
k_{I}=\frac{\alpha_{0}^{I I} \cdot b_{0}^{I I}}{L_{e}}=\frac{1.16 \cdot 110}{2000}=0.064 \\
\beta=\beta_{1}=\frac{1}{1+6.4 \cdot k^{2}}=\frac{1}{1+6.4 \cdot 0.064^{2}}=0.97 \\
\boldsymbol{b}_{\text {eff }}^{I I}=\boldsymbol{\beta}_{\mathbf{1}}^{I I} \cdot \boldsymbol{b}_{\mathbf{0}}^{I I}=\mathbf{0 . 9 7} \cdot \mathbf{1 1 0 0}=\mathbf{1 0 6 7} \mathbf{~} \mathbf{m m}
\end{gathered}
$$


Using the simplified formula, the results will be:

$$
b_{\text {eff }}=\min \left(b_{0} ; \frac{L}{8}\right)=b_{0}^{I, I I}=\left\{\begin{array}{l}
1600 \mathrm{~mm}-\text { for internal element } \\
1100 \mathrm{~mm}-\text { for outstand element }
\end{array}\right.
$$

The minimum value of the bending stresses are as follows:

$\sigma_{2}=\sigma_{\min }=1.25 \cdot(\beta-0.20) \sigma_{1}$

$$
=\left\{\begin{array}{l}
0.925 \cdot \sigma_{1}-\text { for internal element } \\
0.962 \cdot \sigma_{1}-\text { for outstand element }
\end{array}\right.
$$

\section{Effectives $^{\mathrm{s}}$ width and the shear lag at ultimate limit state (ULS)}

The effect of plate buckling in the elastic global analysis and ULS may be neglected because the condition (Beg et al., 2010), $A_{e f f}>\rho f_{f_{\text {lim }}}$ is fulfilled. For a more exact evaluation of the shear lag effect the method $c$ ) recommended by EN1993-1-5 is used.

An elastoplastic reduction factor $\boldsymbol{\beta}^{\boldsymbol{k}} \geq \boldsymbol{\beta}$ is directly applied to the effective $^{\mathrm{p}}$ area of the compression flange, where $\mathrm{k}$ is based on $\boldsymbol{\alpha}_{\mathbf{0}}$ :

$$
\begin{gathered}
A_{\text {eff }}=\boldsymbol{\beta}^{\boldsymbol{k}} \cdot \boldsymbol{A}_{\text {c.eff }} \geq \boldsymbol{A}_{\text {c.eff }} \cdot \boldsymbol{\beta} \quad \text { or: } \\
\boldsymbol{A}_{\text {eff }}=\boldsymbol{\beta}_{e-p} \cdot \boldsymbol{A}_{\text {c.eff }} ; \quad \boldsymbol{\beta}_{e-p}=\max \left(\boldsymbol{\beta}^{\boldsymbol{k}} ; \boldsymbol{\beta}\right)
\end{gathered}
$$

From the Fig. 7 and Fig. 8 it is obtained:

$$
A_{\text {eff }}^{I, I I}=\left\{\begin{array}{l}
0.94^{0.098} \cdot 214.4=213 \mathrm{~cm}^{2}>214.4 \cdot 0.94=202 \mathrm{~cm}^{2} \\
0.97^{0.064} \cdot 138=137.7>138 \cdot 0.97=133.4 \mathrm{~cm}^{2}
\end{array}\right.
$$

It can be noticed that in this case the difference between $A_{\text {eff }}$ and $A_{c . \text { eff }}$ is not significant.

\section{Conclusions and Final Remarks}

The term shear lag is related to some of the discrepancies between the approximate theory of the bending of beams and their real behaviour and refers 
to the increases of the bending stresses near the flange-to-web junctions, and the corresponding decreases in the flange stresses away from these junctions.

In relation to the effective width method, SR EN 1993-1-5.\$3.3 introduces three different designations for three types of effective width:

- Effective ${ }^{\mathrm{s}}$ width - shear lag effects;

- Effective ${ }^{\mathrm{p}}$ width - local buckling of plates;

- Effective width - interaction of shear lag and local buckling (method recommended in the norm EN1993-1-5).

It should be noticed that, the more stiffened the flange is, the smaller its effective $e^{\mathrm{s}}$ width results, but this influence is not very important in hogging bending moment region.

According to EN 1993-1-5, the shear lag in the flanges may be neglected if $\mathrm{b}_{0}<\mathrm{L}_{\mathrm{e}} / 50$.

When designing plated structures, the effects of shear lag, plate buckling and interaction of both effects should be taken into account at the ultimate, serviceability or fatigue limit states, because the shear lag and plate buckling reduce the stiffness of the plated structures.

The design example presented in this paper is useful in the design activity and also to understand the evaluation of the shear lag effects according to EC1993-1-5.

In some cases, the difference between $A_{\text {eff }}$ and $A_{\text {c.eff }}$ is not significant.

\section{REFERENCES}

Trahair, N.S., Bradford, M.A., Nethercot, D.A., Gardner, L.: The behaviour and design of steel structures to EC3. Taylor \& Francis. London. Fourth edition. 2008.

*** SR EN 1993-1-5: 2006. Eurocod 3 (EC3-1-5): Proiectarea structurilor de oţel. Partea 1-5: Elemente din plăci plane solicitate in planul lor.

Beg, D., Kuhlmann, U., Davaine, L., Braun, B.: Design of Plated Structures. ECCS. 2010

Johansson, B., Maquoi, R., Sedlacek, G., Müller, C., Beg, D.: Commentary and worked examples to EN 1993-1-5 „Plated structural elements” (programme of CEN/TC 250). 2007

Moga, C., Feneşan, Crina, Suciu, M.: Effective width of steel flange girders related to shear lag phenomenon. Buletinul Univ. Tehn. „Gh. Asachi”. Vol. 66. Nr. $1 / 2020$

Moga, C., Drăgan, Delia, Nerişanu, Raluca: Effects of Shear Lag in Steel Box Girders of a Crane Runway. Ovidius University Annals Series: Civil Engineering. 2020

Moga, P.: Euronorme. Calculul elementelor metalice. UT Press, 2018

Moga, P., Guțiu, Șt., Moga, C.: Pasarele pietonale. UT Press, 2020 


\section{INTERACŢIUNEA DINTRE FENOMENUL „SHEAR LAG” ŞI VOALAREA LOCALĂ LA PLATELAJELE ORTOTROPE DE PODURI METALICE}

\section{(Rezumat)}

În teoria clasică de încovoiere, deformațiile specifice din forfecare sunt neglijate, astfel încât o secțiune plană rămâne plană și după deformația produsă sub efectul încărcării.

Prin acceptarea acestei ipoteze, rezultă distribuția liniară a deformațiilor și tensiunilor din încovoiere, respectiv distribuţia cunoscută a eforturilor unitare tangențiale.

Fenomenul „shear lag” este legat de discordanța între teoria clasică de încovoiere a grinzii și comportarea reală a acesteia, în particular cea referitoare la creșterea eforturilor unitare din încovoiere la nivelul legăturii talpă-inimă și corespunzător, scăderea acestora în talpă, la o anumită distanță de această zonă de conexiune.

În cazul structurilor cu tălpi dezvoltate, cum este cazul grinzilor de poduri metalice tip cheson cu platelaj ortotrop, efectul ,shear lag” trebuie luat în considerare prin introducerea unei lățimi efective ${ }^{\mathrm{s}}$ reduse, pe lățimea căreia eforturile unitare normale din încovoiere se consideră constante și egale cu valoarea maximă a acestora calculată prin teoria clasică de încovoiere (formula lui Navier).

În lucrare se prezintă câteva aspecte teoretice privind fenomenul „shear lag” și evaluarea lățimii efectives , precum și un exemplu de calcul pentru structura metalică a unei pasarele pietonale de tip cheson metalic cu platelaj ortotrop. 